\title{
Microbial Consortia: Promising Probiotics as Plant Biostimulants for Sustainable Agriculture
}

\author{
Sheridan L. Woo ${ }^{1,2,3 *}$ and Olimpia Pepe ${ }^{3,4,5 *}$ \\ ${ }^{1}$ Department of Pharmacy, University of Naples Federico II, Naples, Italy, ${ }^{2}$ National Research Council, Institute for \\ Sustainable Plant Protection, Portici, Italy, ${ }^{3}$ Task Force on Microbiome Studies, University of Naples Federico II, Naples, Italy, \\ ${ }^{4}$ Department of Agricultural Sciences, University of Naples Federico II, Portici, Italy, ${ }^{5}$ CIRAM-Interdepartmental Center for \\ Environmental Research, University of Naples Federico II, Naples, Italy
}

Keywords: beneficial microbes, plant growth promotion, Trichoderma, Azotobacter, improved crop production

\section{OPEN ACCESS}

Edited by:

Giuseppe Colla,

Università degli Studi della Tuscia, Italy

Reviewed by:

Andrea Ertani,

Università degli Studi di Padova, Italy Claudio Altomare,

Italian National Research Council, Italy

Enrique Monte,

University of Salamanca, Spain

${ }^{*}$ Correspondence:

Sheridan L. Woo

woo@unina.it

Olimpia Pepe

olipepe@unina.it

Specialty section:

This article was submitted to

Crop and Product Physiology,

a section of the journal

Frontiers in Plant Science

Received: 30 September 2018 Accepted: 19 November 2018

Published: 04 December 2018

Citation:

Woo SL and Pepe O (2018) Microbial

Consortia: Promising Probiotics as

Plant Biostimulants for Sustainable

Agriculture. Front. Plant Sci. 9:1801.

doi: 10.3389/fp/s.2018.01801

\section{PLANT “BIO"-STIMULANTS}

Plant biostimulants are applied to improve crop production and nutritional quality of agrifood products. They are often included in agricultural management practices aimed at reducing chemical inputs, increasing productivity and recovering the natural equilibrium in agro-ecosystems.

The widely accepted definition of plant biostimulants (see EBIC, 2013; du Jardin, 2015) is: substance(s) and/or micro-organisms whose function when applied to plants or the soil rhizosphere stimulates the natural processes to enhance/benefit nutrient uptake and efficiency, tolerance to abiotic stress, and crop quality. Typically, biostimulants do not have a direct action against pests.

Commercial formulations may contain a mix of: humic and fulvic acids, amino acids, seaweeds or plant extracts, natural poly- and oligo-mers, chemical elements ( $\mathrm{Al}, \mathrm{Co}, \mathrm{Na}, \mathrm{Se}$, and $\mathrm{Si}$ ), beneficial fungi or bacteria (du Jardin, 2015; Yakhin et al., 2017). Not all listed components are "biological," which makes the term "bio"-stimulant somewhat ambiguous. The "bio" designation may be attributed to the living organism components, and their natural substances. Instead, the non-organic factors can be considered as positive effectors of the "biological" processes that regulate the plant physiology, metabolism, morphology and interactions within the agroecosystem.

\section{REGULATORY LEGISLATION-PLANT PROTECTION PRODUCTS VS. PLANT FERTILIZERS}

The registration of agricultural products in Europe follows two distinct legislation pathways: Plant Protection Products (PPPs) or Fertilizers. PPPs, including microbes and chemicals, as defined in Regulation (EC) $)^{1}$, protect plants or plant products against harmful organisms, influence the life process of plants (i.e., affect plant growth, but are not nutrients), preserve plant products, destroy undesired plants or their parts. The PPP registration process is cumbersome and often not suitable for plant biostimulants (du Jardin, 2015), for which companies seek permission for their use as Fertilizers (see Regulation $(\mathrm{EC})^{2}$, that would also reduce time and expenses required for product registration.

\footnotetext{
${ }^{1}$ Regulation (EC) No 1107/2009 of the European Parliament and of the Council of 21 October 2009 Concerning the Placing of Plant Protection Products on the Market and Repealing Council Directives 79/117/EEC and 91/414/EEC. Available online at: https://eur-lex.europa.eu/legal-content/EN/TXT/?uri=celex\%3A32009R1107 (Latest consolidated version: 02/08/2018)

${ }^{2}$ Regulation (EC) No 2003/2003 of the European Parliament and of the Council of 13 October 2003 Relating to Fertilisers (Text With EEA Relevance). Available online at: https://eur-lex.europa.eu/legal-content/EN/TXT/?qid=1537797652760\& uri=CELEX:32003R2003 (Latest consolidated version: 01/07/2017).
} 
To date, regulatory processes designed for plant biostimulants have not been established. Official definitions and the basic principles for new legislation are still being discussed both in the EU and the U.S.A (du Jardin, 2015). To this end, it is important to consider the inclusion in the registration pipeline of Plant Growth Promoting Microbes (PGPM): microbial individuals and consortia, their bioactive compounds, and potential multi-component mixtures-as they are important components of many successful plant biostimulant products.

Numerous microorganisms, such as Trichoderma spp., are registered as PPPs and classified as Microbial Biological Control Agents (MBCA; Woo et al., 2014). Although single strains are enlisted as biopesticides, many are also known to have properties that result in plant growth promotion and other beneficial effects (Lorito and Woo, 2015), typically not indicated in the registered product disclaimer. Conversely, there are plant biostimulants such as arbuscular mycorrhizal fungi (AMF; Rouphael et al., 2015), that are also capable of inducing systemic resistance conferring crop protection to disease and pest attack (Cameron et al., 2013). This means that there is an urgent need to create a new registration track for microbes or microbial consortia with multiple plant beneficial functions (e.g., MBCA and PGPM) in order to regulate the use of effective agricultural products that are "all inclusive" (e.g., biostimulant, biofertilizer, biopesticide).

\section{PLANT GROWTH PROMOTING MICROBES (PGPM) IN BENEFICIAL MICROBIAL CONSORTIA}

Important examples of positive plant-microbe interactions associated to plant growth promotion include PGP rhizobacteria: non-pathogenic Pseudomonas and Bacillus, Azotobacter, Serratia, Azospirillum capable of improving nutrient availability in soil, plant nutrient uptake and assimilation, as well as supporting nitrogen cycling (Raaijmakers et al., 2009; Berg et al., 2014; Lugtenberg, 2015).

PGPM of fungal origins are widely applied, but less recognized in the literature. The best documented example is that of the mycorrhizal fungi (AMF, VAM) including Gigaspora, Funneliformis or Rhizophagus (Glomus), and Laccaria, that are root obligate biotrophs able to establish mutualistic symbiosis with $>80 \%$ of vascular plant species (Pringle et al., 2009; Rouphael et al., 2015). They are involved in carbon exchange, and augment the capacity of the plant to absorb water plus nutrients, thus counteracting negative effects of biotic and abiotic stresses. Another case is the fungus Trichoderma. It is an active ingredient in hundreds of agricultural products commercialized worldwide (Woo et al., 2014), it has multiple beneficial effects on plants (Harman et al., 2004), and used extensively in biological and integrated pest management (Lorito and Woo, 2015).

Many recent studies demonstrate the potential as plant biostimulants of microbial consortia, rhizobacteria, and rhizofungi, that function as an agricultural probiotics (de Vries and Wallenstein, 2017; Wallenstein, 2017; Kong et al., 2018). The present work describes an example of two prospective microbes and their qualities as consortium components.

\section{Trichoderma: the Evolving MBCA With Multiple Plant Beneficial Effects}

Numerous strains of Trichoderma are successful MBCA of various plant pathogens. Initially, the biopesticidal activity was considered as the only benefit, but eventually these MBCA were demonstrated to be effective biofertilizers, biostimulants, bio-enhancers of crop resistance to both biotic and abiotic stresses (Harman et al., 2004; Fontenelle et al., 2011; Lorito and Woo, 2015). In fact, scientific evidence demonstrated that the PGP effect could be the result of a true symbiotic interaction (Harman et al., 2004; Vinale et al., 2008; Shoresh et al., 2010; Studholme et al., 2013; Lorito and Woo, 2015).

In certain conditions, Trichoderma may activate a state of alert in the plant (i.e., priming), thus producing a ready response to pathogen attack, which eventually anticipates the establishment of a Systemic Acquired Resistance (SAR) and/or Induced Systemic Resistance (ISR; Rubio et al., 2014; Hossain et al., 2017; Martínez-Medina et al., 2017; Manganiello et al., 2018). Furthermore, results from laboratory and field tests with Trichoderma, performed on a variety of crops, have shown a reduction in symptoms caused by abiotic diseases (e.g., water, salt, nutrients) following treatments (Mastouri et al., 2012; Brotman et al., 2013; Sofo et al., 2014; Fiorentino et al., 2018).

Improvement in plant development is typically noted with increased seed germination, above- and below-ground plant parts, chlorophyll content and yield, size and/or number of flowers and/or fruits (Harman et al., 2004; Hermosa et al., 2012; Studholme et al., 2013; Mendoza-Mendoza et al., 2018). In particular, modifications to the roots increases the area of absorption, improving nutrient uptake and translocation, then the efficient use of NPK and micronutrients attributes to enhanced plant biomass (Samolski et al., 2012). The PGP effect is attributed to the role of Trichoderma in the solubilization of phosphate and micronutrients (Altomare et al., 1999), mediated by the release of siderophores and secondary metabolites (Vinale et al., 2009, 2013, 2014; Spaepen, 2015), or modifications in ethylene and auxin (Hermosa et al., 2013; Contreras-Cornejo et al., 2015) that stimulate plant development.

Trichoderma spp. produce over 250 metabolic products including cell wall degrading enzymes, peptides, secondary metabolites and other proteins (Sivasithamparam and Ghisalberti, 1998; Harman et al., 2004; Morán-Diez et al., 2009; Lorito et al., 2010; Keswani et al., 2014; Ruocco et al., 2015). Many of these compounds are bioactive and can affect the plant response to other microbes, by improving defense mechanisms, while stimulating plant growth and development, especially at the root level (Sivasthamparam and Ghisalberti, 1998; Vinale et al., 2009, 2013; Lombardi et al., 2018). Synergistic effects on biocontrol have been found in many combinations of 
diverse strains, metabolites, mixtures of bioactive compounds, originating from Trichoderma as well as other microbes or plants, which suggests a wealth of possibilities for developing a new generation of biostimulants.

\section{Azotobacter: Rhizocompetent Stress Tolerant $\mathbf{N}_{2}$ Free-Living Bacteria}

Azotobacter includes free-living species that directly influence nutrition in agroecosystems through nitrogen fixation, thus increasing the soil level of this vital element for plants. The bacterium has the ability to form heat and desiccation-resistant cysts, providing inoculant with a long shelf-life (Inamdar et al., 2000) and tolerance to drought and salinity stress (Vacheron et al., 2013; Berg et al., 2014; Viscardi et al., 2016). In its resistant form, Azotobacter can withstand biotic and abiotic stresses while positively interacting with other microrganisms and plants in agroecosystems (Babalola, 2010; Ahmad et al., 2011; Berendsen et al., 2012; Bhattacharyya and Jha, 2012; Gaiero et al., 2013; Philippot et al., 2013). Numerous commercial biofertilizer products contain Azotobacter as active ingredients, often in association with fungi, actinomycetes as well as other bacteria (e.g., bacilli; EBIC, 2013).

The ability of beneficial Azotobacter strains to secrete plant growth promoting and regulating substances such as phytohormones, vitamins, and antifungal metabolites have been studied. Phosphate solubilization (Hariprasad and Niranjana, 2009; Rojas-Tapias et al., 2012; Wani et al., 2013) and Fe mobilization (Rizvi and Khan, 2018) have been demonstrated in vitro and in soil, also under abiotic stress conditions (Viscardi et al., 2016; Van Oosten et al., 2018).

Furthermore, the Azotobacter-mediated synthesis of superoxide dismutase (SOD), catalase (CAT), proline, and high levels of 1-aminocyclopropane-1-carboxylate (ACC) activity (Glick, 2014) can influence plant health and bring benefits to a wide variety of crops such as tomato (Viscardi et al., 2016), maize (Rojas-Tapias et al., 2012), rice, wheat, and sorghum (Inamdar et al., 2000; Di Stasio et al., 2017; Van Oosten et al., 2018). Barra et al. (2016) confirmed the importance of ACC deaminase (ACCd) activity and indole-3acetic acid (IAA) production for the alleviation of salt stress in plants treated with rhizo-competent stress tolerant Azotobacter strains. Similarly, a model proposed by Hermosa et al. (2012) indicated that the ACCd and IAAs produced by Trichoderma also regulated the equilibrium between plant growth and defense.

\section{AGRICULTURAL PROBIOTICS: MICROBIAL CONSORTIA TO ENHANCE PGP EFFICACY}

Recently, a new approach to "rhizosphere engineering" proposes the addition of effective microbial inoculants to emulate the structured biological networks in native soils, thus stimulating the recovery of functional, beneficial microbial groups positively linked to soil fertility (Ruzzi and Aroca, 2015; Shi et al., 2016; Wallenstein, 2017; Stringlis et al., 2018), and replenishing the natural microbiome reduced by crop domestication (Leff et al., 2016; Perez-Jaramillo et al., 2016). These treatments may activate nitrogen fixation, phosphate solubilization, siderophore, phytohormone, and exopolysaccharide production known to enhance growth while protecting the plant from abiotic stresses, e.g., extreme temperature, $\mathrm{pH}$, salinity, drought (Ashraf et al., 2004; Compant et al., 2005; Gopalakrishnan et al., 2015; Viscardi et al., 2016; Van Oosten et al., 2017), plus heavy metal, and pesticide pollution (Ventorino et al., 2014). Even though knowledge is limited on the survival of the microbial inoculants, the ability of rhizosphere competent bacteria and fungi to establish close associations with the native microbiota and soil fauna has been sufficiently demonstrated (Hardoim et al., 2015; Bonanomi et al., 2017, 2018; de Vries and Wallenstein, 2017). The synthetic bacteria-fungi consortia have the potential to establish novel microbial communities (Ahmad et al., 2011; Berg et al., 2014; du Jardin, 2015; Lugtenberg, 2015), while co-applications of different microbes may activate new PGP effects not obtained by using single species (Wargo and Hogan, 2006).

Plant microbiome engineering requires the identification and culturing of potential PGPMs, deep analysis/selection of the various components, evaluation of the compatibility between microorganisms, determination of the cause and effects in the native agroecosystem, development of adequate formulation recipes and distribution technology, plus provision of technical support to end-users (Berendsen et al., 2012; Berg et al., 2014; Lugtenberg, 2015; Yakhin et al., 2017; Kong et al., 2018). To this end, the extensive studies on Trichoderma and Azotobacter suggest that these fungi and bacteria could be functionally complementary in a PGP consortium, although the effects on the resident rhizosphere microbiota have not been sufficiently elucidated. Furthermore, the TrichodermaAzotobacter consortia could be integrated with botanical and inorganic compounds, seaweeds, polymers, animal-derived products to develop truly effective, and reliable beneficial plant products. 'Omics studies can reveal basic mechanisms regulating these complex interactions and provide new knowledge concentrated on the mechanisms that could be relevant for improving the next generation of plant biostimulants (Bell et al., 2015; Soni et al., 2017; Fiorentino et al., 2018; Ventorino et al., 2018).

The global biopesticide market is continuously growing due to changing agricultural legislations and regulations, increased demand for biological/organic products, conversions from conventional to integrated pest management (IPM), and organic farming systems (Woo et al., 2014; Lugtenberg, 2015). Similarly, a steady growth is observed in the biofertilizer market (about 10\% per year; EBIC, 2013). The new frontier for plant biostimulants should profit from the beneficial associations of microorganisms and compounds, by building on a deeper understanding of plant-microbe interactions developed by Nature. New microbial consortium can be designed, e.g., Trichoderma plus Azotobacter, as agricultural probiotics suitable for sustaining the agroecosystem while improving the quantity and quality of yield. 


\section{AUTHOR CONTRIBUTIONS}

SW and OP conceived the concepts and wrote the manuscript in collaboration.

\section{FUNDING}

JGI Community Scientific Program 2016, Proposal 1966-CSP 2016; Project ProBio - IZSM (Portici), n. D01 6309, 14/12/2016;

\section{REFERENCES}

Ahmad, I., Khan, M. S. A., Aqil, F., and Singh, M. (2011). "Microbial applications in agriculture and the environment: a broad perspective," in Microbes and Microbial Technology: Agricultural and Environmental Applications, eds I. Ahmad, F. Ahmad, and J. Pichtel (New York, NY: Springer), 1-27.

Altomare, C., Norvell, W. A., Bjorkman, T., and Harman, G. E. (1999). Solubilization of phosphates and micronutrients by the plant-growthpromoting and biocontrol fungus Trichoderma harzianum Rifai 1295-22. Appl. Environ. Microbiol. 65, 2926-2933.

Ashraf, M., Hasnain, S., Berge, O., and Mahmood, T. (2004). Inoculating wheat seedlings with exopolysaccharide-producing bacteria restricts sodium uptake and stimulates plant growth under salt stress. Biol. Fertil. Soils 40, 157-162. doi: 10.1007/s00374-004-0766-y

Babalola, O. O. (2010). Beneficial bacteria of agricultural importance. Biotechnol. Lett. 32, 1559-1570. doi: 10.1007/s10529-010-0347-0

Barra, P. J., Inostroza, N. G., Acuña, J. J., Mora, M. L., Crowley, D. E., and Jorquera, M. A. (2016). Formulation of bacterial consortia from avocado (Persea americana Mill.) and their effect on growth, biomass and superoxide dismutase activity of wheat seedlings under salt stress. Appl. Soil Ecol. 102, 80-91. doi: 10.1016/j.apsoil.2016.02.014

Bell, C. W., Asao, S., Calderon, F., Wolk, B., and Wallenstein, M. D. (2015). Plant nitrogen uptake drives rhizosphere bacterial community assembly during plant growth. Soil Biol. Biochem. 85, 170-182. doi: 10.1016/j.soilbio.2015.03.006

Berendsen, R. L., Pieterse, C. M., and Bakker, P. A. (2012). The rhizosphere microbiome and plant health. Trends Plant Sci. 17, 478-486. doi: 10.1016/j.tplants.2012.04.001

Berg, G., Grube, M., Schloter, M., and Smalla, K. (2014). Unraveling the plant microbiome: looking back and future perspectives. Front. Microbiol. 5:148. doi: $10.3389 /$ fmicb.2014.00148

Bhattacharyya, P. N., and Jha, D. K. (2012). Plant growth-promoting rhizobacteria (PGPR): emergence in agriculture. World J. Microbiol. Biotechnol. 28, 1327-1350. doi: 10.1007/s11274-011-0979-9

Bonanomi, G., Ippolito, F., Cesarano, G., Vinale, F., Lombardi, N., Crasto, A., et al. (2017). Biochar chemistry defined by13C-CPMAS NMR explains opposite effects on soilborne microbes and crop plants. Appl. Soil Ecol. 124, 351-361. doi: 10.1016/j.apsoil.2017.11.027

Bonanomi, G., Lorito, M., Vinale, F., and Woo, S. L. (2018). Organic amendments, beneficial microbes, and soil microbiota: toward a unified framework for disease suppression. Annu. Rev. Phytopathol. 56, 1-20. doi: 10.1146/annurev-phyto-080615-100046

Brotman, Y., Landau, U., Cuadros-Inostroza, Á., Tohge, T., Fernie, A. R., Chet, I., et al. (2013). Trichoderma-plant root colonization: escaping early plant defense responses and activation of the antioxidant machinery for saline stress tolerance. PLoS Pathog. 9:e1003221. doi: 10.1371/journal.ppat.1003221

Cameron, D. D., Neal, A. L., van Wees, S. C., and Ton, J. (2013). Mycorrhizainduced resistance: more than the sum of its parts? Trends Plant Sci. 18:539-545. doi: 10.1016/j.tplants..06.004

Compant, S., Duffy, B., Nowak, J., Clément, C., and Barka, E. A. (2005). Use of plant growth-promoting bacteria for biocontrol of plant diseases: principles, mechanisms of action, and future prospects. Appl. Environ. Microbiol. 71, 4951-4959. doi: 10.1128/AEM.71.9.4951-4959.2005

Contreras-Cornejo, H. A., López-Bucio, J. S., Méndez-Bravo, A., MacíasRodríguez, L., Ramos-Vega, M., Guevara-García, Á. A., et al. (2015).
Project SIX - B.U. Regione Puglia, n. 111, 29/9/2016, Cod. C; Project LINFA - MIUR-PON, n. 03PE_00026_1, 09/04/2014; KENYA-AID, n. 10306/CEFA/KEN, 18/05/2017.

\section{ACKNOWLEDGMENTS}

We thank Valeria Ventorino, Francesco Vinale, Nadia Lombardi, and Matteo Lorito for editorial assistance and comments.
Mitogen-activated protein kinase 6 and ethylene and auxin signaling pathways are involved in Arabidopsis root-system architecture alterations by Trichoderma atroviride. Mol. Plant-Microbe Interact. 28, 701-710. doi: 10.1094/MPMI-01-15-0005-R

de Vries, F. T., and Wallenstein, M. D. (2017). Below-ground connections underlying above-ground food production: a framework for optimising ecological connections in the rhizosphere. J. Ecol. 105, 913-920. doi: 10.1111/1365-2745.12783

Di Stasio, E., Maggio, A., Ventorino, V., Pepe, O., Raimondi, G., and De Pascale, S. (2017). Free-living $\left(\mathrm{N}_{2}\right)$-fixing bacteria as potential enhancers of tomato growth under salt stress. Acta Hortic. 1164, 151-156. doi: 10.17660/ActaHortic.2017.1164.19

du Jardin, P. (2015). Plant biostimulants: definition, concept, main categories and regulation. Sci. Hortic. 196, 3-14. doi: 10.1016/j.scienta.2015.09.021

EIBC (European Biostimulants Industry Council) (2013). Promoting the Biostimulant Industry and the Role of Plant Biostimulants in Making Agriculture More Sustainable. Available online at: www.biostimulants.eu/

Fiorentino, N., Ventorino, V., Woo, S. L., Pepe, O., De Rosa, A., Gioia, L., et al. (2018). Trichoderma-based biostimulants modulate rhizosphere microbial populations and improve $\mathrm{N}$ uptake efficiency, yield, and nutritional quality of leafy vegetables. Front. Plant Sci. 9:743. doi: 10.3389/fpls.2018.00743.

Fontenelle, A. D. B., Guzzo, S. D., Lucon, C. M. M., and Harakava, R. (2011). Growth promotion and induction of resistance in tomato plant against Xanthomonas euvesicatoria and Alternaria solani by Trichoderma spp. Crop Prot. 30, 1492-1500. doi: 10.1016/j.cropro.2011.07.019

Gaiero, J. R., McCall, C. A., Thompson, K. A., Dayu, N. J., Best, A. S., and Dunfield, K. E. (2013). Inside the root microbiome: bacterial root endophytes and plant growth promotion. Am. J. Bot. 100, 1738-1750. doi: 10.3732/ajb.1200572

Glick, B. R. (2014). Bacteria with ACC deaminase can promote plant growth and help to feed the world. Microbiol. Res. 169, 30-39. doi: 10.1016/j.micres.2013.09.009

Gopalakrishnan, S., Sathya, A., Vijayabharathi, R., Varshney, R. K., Gowda, C. L. L., and Krishnamurthy, L. (2015). Plant growth promoting rhizobia: challenges and opportunities. 3 Biotech 5, 355-377. doi: 10.1007/s13205-014-0241-x

Hardoim, P. R., van Overbeek, L. S., Berg, G., Pirttil,ä, A. M., Compant, S., Campisano, A., et al. (2015). The hidden world within plants: ecological and evolutionary considerations for defining functioning of microbial endophytes. Microbiol. Mol. Biol. Rev. 79, 293-320. doi: 10.1128/MMBR.00 050-14

Hariprasad, P., and Niranjana, S. R. (2009). Isolation and characterization of phosphate solubilizing rhizobacteria to improve plant health of tomato. Plant Soil 316, 13-24. doi:10.1007/s11104-008-9754-6

Harman, G. E., Howell, C. R., Viterbo, A., Chet, I., and Lorito, M. (2004). Trichoderma species - opportunistic, avirulent plant symbionts. Nat. Rev. Microbiol. 2, 43-56. doi: 10.1038/nrmicro797

Hermosa, R., Rubio, M. B., Cardoza, R. E., Nicolás, C., Monte, E., and Gutiérrez, S. (2013). The contribution of Trichoderma to balancing the costs of plant growth and defense. Int. Microbiol. 16, 69-80. doi: 10.2436/20.1501.01.181

Hermosa, R., Viterbo, A., Chet, I., and Monte, E. (2012). Plant-beneficial effects of Trichoderma and of its genes. Microbiology 158, 17-25. doi: 10.1099/mic.0.052274-0

Hossain, M. M., Sultana, F., and Islam, S. (2017). "Plant Growth-Promoting Fungi (PGPF): Phytostimulation and induced systemic resistance," in Plant-Microbe Interactions in Agro-Ecological Perspectives, Volume 2: Microbial Interactions 
and Agro-Ecological Impacts, eds D. Singh, H. Singh, and R. Prabha (Singapore: Springer), 135-191. doi: 10.1007/978-981-10-6593-4

Inamdar, S., Kanitkar, R. U., and Watve, M. G. (2000). Longevity of Azotobacter cysts and a model for optimization of cyst density in liquid bioinoculants. Curr. Sci. 78, 719-721.

Keswani, C., Mishra, S., Sarma, B. K., Singh, S. P., and Singh, H. B. (2014). Unraveling the efficient applications of secondary metabolites of various Trichoderma spp. Appl. Microbiol. Biotechnol. 98, 533-544. doi: $10.1007 / \mathrm{s} 00253-013-5344-5$

Kong, W., Meldgin, D. R., Collins, J. J., and Lu, T. (2018). Designing microbial consortia with defined social interactions. Nat. Chem. Biol. 14, 821-829. doi: 10.1038/s41589-018-0091-7

Leff, J. W., Lynch, R. C., Kane, N. C., and Fierer, N. (2016). Plant domestication and the assembly of bacterial and fungal communities associated with strains of the common sunflower, Helianthus annuus. New Phytol. 214, 412-423. doi: $10.1111 / \mathrm{nph} .14323$

Lombardi, N., Vitale, S., Turrà, D., Reverberi, M., Fanelli, C., Vinale, F., et al. (2018). Root exudates of stressed plants stimulate and attract Trichoderma soil fungi. Mol. Plant-Microbe Interact. 31, 982-994. doi: 10.1094/MPMI-12-17-0310-R

Lorito, M., and Woo, S. L. (2015). "Trichoderma: a multi-purpose tool for integrated pest management," in Principles of Plant-Microbe Interactions, ed B. Lugtenberg (Cham: Springer International Publishing), 345-353. doi: 10.1007/978-3-319-08575-3_36

Lorito, M., Woo, S. L., Harman, G. E., and Monte, E. (2010). Translational research on Trichoderma: from 'omics to the field. Annu. Rev. Phytopathol. 48, 395-417. doi: 10.1146/annurev-phyto-073009-114314

Lugtenberg, B. (2015). Principles of Plant-Microbe Interactions: Microbes for Sustainable Agriculture. Cham: Springer International Publishing, p. 448.

Manganiello, G., Sacco, A., Ercolano, M. R., Vinale, F., Lanzuise, S., Pascale, A., et al. (2018). Modulation of tomato response to Rhizoctonia solani by Trichoderma harzianum and its secondary metabolite harzianic acid. Front. Microbiol. 9:1966. doi: 10.3389/fmicb.2018.01966

Martínez-Medina, A., Van Wees, S., and Pieterse, C. M. (2017). Airborne signals by Trichoderma fungi stimulate iron uptake responses in roots resulting in priming of jasmonic acid-dependent defences in shoots of Arabidopsis thaliana and Solanum lycopersicum. Plant Cell Environ. 40, 2691-2705. doi: $10.1111 /$ pce. 13016

Mastouri, F., Björkman, T., and Harman, G. E. (2012). Trichoderma harzianum enhances antioxidant defense of tomato seedlings and resistance to water defecit. Mol. Plant-Microbe Interact. 9, 1264-1271. doi: 10.1094/MPMI-09-11-0240

Mendoza-Mendoza, A., Zaid, R., Lawry, R., Hermosa, R., Monte, E., Horwitz, B. A., et al. (2018). Molecular dialogues between Trichoderma and roots: role of the fungal secretome. Fungal Biol. Rev. 32, 62-85. doi: 10.1016/j.fbr.2017.12.001

Morán-Diez, E., Hermosa, R., Ambrosino, P., Cardoza, R. E., Gutiérrez, S., Lorito, M., et al. (2009). The ThPG1 endopolygalacturonase is required for the Trichoderma harzianum-plant beneficial interaction. Mol. Plant-Microbe Interac. 22, 1021-1031. doi: 10.1094/MPMI-22-8-1021

Perez-Jaramillo, J. E., Mendes, R., and Raaijmakers, J. M. (2016). Impact of plant domestication on rhizosphere microbiome assembly and functions. Plant Mol. Biol. 90, 635-644. doi: 10.1007/s11103-015-0337-7

Philippot, L., Raaijmakers, J. M., Lemanceau, P., and van der Putten, W. H. (2013). Going back to the roots: the microbial ecology of the rhizosphere. Nat. Rev. Microbiol. 11, 789-799. doi: 10.1038/nrmicro3109

Pringle, A., J. D., Bever, M., Gardes, J. L., Parrent, M. C., and Rillig, and, J. N., Klironomos, (2009). Mycorrhizal symbioses and plant invasions. Annu. Rev. Ecol. Syst. 40, 699-715. doi: 10.1146/annurev.ecolsys.39.110707.173454

Raaijmakers, J. M., Paulitz, T. C., Steinberg, C., Alabouvette, C., and MoënneLoccoz, Y. (2009). The rhizosphere: a playground and battlefield for soilborne pathogens and beneficial microorganisms. Plant Soil 321, 341-361. doi: 10.1007/s11104-008-9568-6

Rizvi, A., and Khan, M. S. (2018). Heavy metal induced oxidative damage and root morphology alterations of maize (Zea mays L.) plants and stress mitigation by metal tolerant nitrogen fixing Azotobacter chroococcum. Ecotoxicol. Environ. Saf. 157, 9-20. doi: 10.1016/j.ecoenv.2018.03.063

Rojas-Tapias, D., Moreno-Galván, A., Pardo-Díaz, S., Obando, M., Rivera, D., and Bonilla, R. (2012). Effect of inoculation with plant growth-promoting bacteria
(PGPB) on amelioration of saline stress in maize (Zea mays). Appl. Soil Ecol. 61, 264-272. doi: 10.1016/j.apsoil.2012.01.006

Rouphael, Y. P., Franken, C., Schneider, D., Schwarz, M., Giovannetti, M., Agnolucci, S., et al. (2015). Arbuscular mycorrhizal fungi act as biostimulants in horticultural crops. Sci. Hortic. 196, 91-108. doi: 10.1016/j.scienta.2015.09.002

Rubio, B. M., Quijada, N. M., Pérez, E., Domínguez, S., Monte, E., and Hermosa, R. (2014). Identifying beneficial qualities of Trichoderma parareesei for plants. Appl. Environ. Microbiol 6, 1864-1873. doi: 10.1128/AEM.03375-13

Ruocco, M., Lanzuise, S., Lombardi, N., Woo, S. L., Vinale, F., Marra, R., et al. (2015). Multiple roles and effects of a novel Trichoderma hydrophobin. Mol. Plant-Microbe Interact. 28, 167-179. doi: 10.1094/MPMI-07-14-0194-R

Ruzzi, M., and Aroca, R. (2015). Plant growth-promoting rhizobacteria act as biostimulants in horticulture. Sci. Hortic. 196, 124-134. doi: 10.1016/j.scienta.2015.08.042

Samolski, I., Rincón, A. M., Pinzón, L. M., Viterbo, A., and Monte, E. (2012). The qid74 gene from Trichoderma harzianum has a role in root architecture and plant biofertilization. Microbiology 158, 129-138. doi: 10.1099/mic.0.053140-0

Shi, S., Nuccio, E. E., Shi, Z. J., He, Z., Zhou, J., and Firestone, M. K. (2016). The interconnected rhizosphere: high network complexity dominates rhizosphere assemblages. Ecol. Lett. 19, 926-936. doi: 10.1111/ele.12630

Shoresh, M., Harman, G. E., and Mastouri, F. (2010). Induced systemic resistance and plant responses to fungal biocontrol agents. Annu. Rev. Phytopathol. 48, 21-43. doi: 10.1146/annurev-phyto-073009-114450

Sivasithamparam, K., and Ghisalberti, E. L. (1998). "Secondary metabolism in Trichoderma and Gliocladium," in Trichoderma and Gliocladium. Volume 1: Basic Biology, Taxonomy and Genetics, eds G. E. Harman and C. P. Kubicek (London: Taylor and Francis Ltd.), 139-191.

Sofo, A., Nuzzaci, M., Vitti, A., Tataranni, G., and Scopa, A. (2014). "Control of biotic and abiotic stresses in cultivated plants by the use of biostimulant microorganisms," in Improvement of Crops in the Era of Climatic Changes, eds P. Ahmad, M. Wani, M. Azooz, and L. S. Tran (New York, NY: Springer), 107-117. doi: 10.1007/978-1-4614-8830-9_5

Soni, R., Kumar, V., Suyal, D. C., Jain, L., and Goel, R. (2017). "Metagenomics of plant rhizosphere microbiome," in Understanding Host-Microbiome Interactions - An Omics Approach, eds R. Singh, R. Kothari, P. Koringa, and S. Singh (Singapore: Springer), 193-205. doi: 10.1007/978-981-10-5050-3_12.

Spaepen, S. (2015). "Plant hormones produced by microbes," in Principles of Plant-Microbe Interactions, ed B. Lugtenberg (Cham: Springer International Publishing), 247-256. doi: 10.1007/978-3-319-08575-3_26

Stringlis, I. A., Zhang, H., Pieterse, C. M. J., Bolton, M. D., and de Jonge, R. (2018). Microbial small molecules - weapons of plant subversion. Nat. Prod. Rep. 35, 410-433. doi: 10.1039/c7np00062f

Studholme, D. J., Harris, B., Le Cocq, K., Winsbury, R., Perera, V., Ryder, L., et al. (2013). Investigating the beneficial traits of Trichoderma hamatum GD12 for sustainable agriculture - insights from genomics. Front. Plant Sci. 4:258. doi: 10.3389/fpls.2013.00258

Vacheron, J., Desbrosse, G., Bouffaud, M. L., Touraine, B., Moënne-Loccoz, Y., Muller, D., et al. (2013). Plant growth-promoting rhizobacteria and root system functioning. Front. Plant Sci. 4:356. doi: 10.3389/fpls.2013.00356.

Van Oosten, M. J., Di Stasio, E., Cirillo, V., Silletti, S., Ventorino, V., Pepe, O., et al. (2018). Root inoculation with Azotobacter chroococcum 76A enhances tomato plants adaptation to salt stress under low $\mathrm{N}$ conditions. BMC Plant Biol. 18:205. doi: 10.1186/s12870-018-1411-5

Van Oosten, M. J., Pepe, O., De Pascale, S., Silletti, S., and Maggio, A. (2017). The role of biostimulants and bioeffectors as alleviators of abiotic stress in crop plants. Chem. Biol. Technol. Agric. 4:5. doi: 10.1186/s40538-017-0089-5

Ventorino, V., Pascale, A., Adamo, P., Rocco, C., Fiorentino, N., Mori, M., et al. (2018). Comparative assessment of autochthonous bacterial and fungal communities and microbial biomarkers of polluted agricultural soils of the Terra dei Fuochi. Sci. Rep. 8:14281. doi: 10.1038/s41598-018-32 688-5

Ventorino, V., Sannino, S., Piccolo, A., Cafaro, V., Carotenuto, R., and Pepe, O. (2014). Methylobacterium populi VP2: plant growth-promoting bacterium isolated from a highly polluted environment for polycyclic aromatic hydrocarbon (PAH) biodegradation. Sci. World J. 2014, 1-11. doi: $10.1155 / 2014 / 931793$

Vinale, F., Flematti, G., Sivasithamparam, K., Lorito, M., Marra, R., Skelton, B. W., et al. (2009). Harzianic acid, an antifungal and plant growth promoting 
metabolite from Trichoderma harzianum. J. Nat. Prod. 72, 2032-2035. doi: $10.1021 / \mathrm{np} 900548 \mathrm{p}$

Vinale, F., Manganiello, G., Nigro, M., Mazzei, P., Piccolo, A., Pascale, A., et al. (2014). A novel fungal metabolite with beneficial properties for agricultural applications. Molecules 19, 9760-9772. doi: 10.3390/molecules190 79760

Vinale, F., Nigro, M., Sivasithamparam, K., Flematti, G., Ghisalberti, E. L., Ruocco, M., et al. (2013). Harzianic acid: a novel siderophore from Trichoderma harzianum. FEMS Microbiol. Lett. 347, 123-129. doi: 10.1111/1574-6968.12231

Vinale, F., Sivasithamparam, K., Ghisalberti, E. L., Marra, R., Barbetti, M. J., Li, H., et al. (2008). A novel role for Trichoderma secondary metabolites in the interactions with plants. Physiol. Mol. Plant Pathol. 72, 80-86. doi: 10.1016/j.pmpp.2008. 05.005

Viscardi, S., Ventorino, V., Duran, P., Maggio, A., De Pascale, S., Mora, M. L., et al. (2016). Assessment of plant growth promoting activities and abiotic stress tolerance of Azotobacter chroococcum strains for a potential use in sustainable agriculture. J. Soil Sci. Plant Nutr. 16, 848-863. doi: 10.4067/S0718-951620160050 00060

Wallenstein, M. D. (2017). Managing and manipulating the rhizosphere microbiome for plant health: a systems approach. Rhizosphere 3, 230-232. doi: 10.1016/j.rhisph.2017.04.004
Wani, S. A., Chand, S., and Ali, T. (2013). Potential use of Azotobacter chroococcum in crop production: an overview. Curr. Agr. Res. J. 1, 35-38. doi: 10.12944/CARJ.1.1.04

Wargo, M. J., and Hogan, D. A. (2006). Fungal-bacterial interactions: a mixed bag of mingling microbes. Curr. Opin. Microbiol. 9, 359-364. doi:10.1016/j.mib.2006.06.001

Woo, S. L., Ruocco, M., Vinale, F., Nigro, M., Marra, R., Lombardi, N., et al. (2014). Trichoderma-based products and their widespread use in agriculture. Open Mycol. J. 8, 71-126. doi: 10.2174/1874437001408010071

Yakhin, O. I., Lubyanov, A. A., Yakhin, I. A., and Brown, P. H. (2017). Biostimulants in plant science: a global perspective. Front. Plant Sci. 7:2049. doi: $10.3389 /$ fpls.2016.02049

Conflict of Interest Statement: The authors declare that the research was conducted in the absence of any commercial or financial relationships that could be construed as a potential conflict of interest.

Copyright $(2018$ Woo and Pepe. This is an open-access article distributed under the terms of the Creative Commons Attribution License (CC BY). The use, distribution or reproduction in other forums is permitted, provided the original author $(s)$ and the copyright owner(s) are credited and that the original publication in this journal is cited, in accordance with accepted academic practice. No use, distribution or reproduction is permitted which does not comply with these terms. 